DOI https://doi.org/10.15407/usim.2020.02.023

UDK 364.2:331; 681.513

L.M. KOLIECHKINA, Doctor (Phys.-Math.), Professor, University of Lodz, 22 Banaha st., Lodz, 90-238, Poland, lkoliechkina@gmail.com

O.A. DVIRNA,PhD (Phys.-Math.), Assistant, Poltava University of Economics and Trade, 3 Koval st., Poltava, 36000, Ukraine, lenadvirna@gmail.com

A.M. NAHIRNA, PhD, (Phys.-Math.), Associate Professor, National University of "Kyiv-Mohyla Academy", 2 Skovoroda st., Kyiv, 04070, Ukraine, naghirnaalla@ukr.net

\title{
CONSTRUCTION OF A MATHEMATICAL MODEL OF MULTIOBJECTIVE OPTIMIZATION ON PERMUTATIONS
}

The article is devoted to the problem of constructing and solving mathematical models of applied problems as multiobjective problems on combinatorial configurations. This question is actual branch because any task of optimal design of complex economic and technical systems, technological devices, planning and management etc. requires that the desired solution be found consider many criteria. It is used transfer to Euclidian combinatorial configurations and using of discrete optimizations methods. Method for solving such problems is considered and it includes the analyzing of structural graph of Euclidean combinatorial configurations sets. These methods can be modified by combining with other multiobjective optimization approaches depending on the initial conditions of the problem. Models for defining real estate contribution plans and production planning as multiobjective discrete problems are proposed. These models can be supplemented as needed by the required functions and, depending on the initial conditions, are presented as tasks on different sets of combinatorial configurations.

Keywords: optimization problems, combinatorial configurations, Euclidean combinatorial set, optimization problems model, optimal solutions set.

\section{Introduction}

The optimization problems with several functions arise in the investigation of many theoretical and applied problems [1-5]. Almost any task of optimal design of complex economic and technical systems, schemes, technological devices, structures, planning and management of industrial and commercial activities, identification of model parameters by experimental data, etc. requires that the desired solution be found consider many criteria. Ac- cordingly, since it is impossible to adequately express the conditions of the problem with one complex criterion, it is more expedient to use the multiobjective optimization apparatus to take into account all the requirements of the applied problem. It means that a classical single-criterion optimization's approaches are insufficient for searching and adoption of effective solutions to applied problems.

Also problems on combinatorial configurations are of more practical interest [5-8]. The combinatorial properties of the feasible solutions field 
and their application are very well represented in the classic problems of the salesman task and enterprise planning task.

Consideration of a problem model that takes into account the properties of multi-criteria and combinatorial properties of the feasible solutions is interesting from a practical point of view. Such problems are models of many applied problems and are described in [3-5].

\section{Formulation of the Problem}

\section{Combinatorial multiobjective problem}

Let mappings $\varphi_{i}: \Pi^{\prime} \rightarrow R^{1}, i \in J_{n}, J_{n}=\{1,2, \ldots, n\}$ be given on a combinatorial set. Then they can be written as a vector criterion

$$
\Phi(\pi)=\left(\varphi_{1}(\pi), \varphi_{2}(\pi), \ldots, \varphi_{v}(\pi)\right) .
$$

In the case of such an optimality criterion, we are talking about a multiobjectivecombinatorial optimization problem (MCOP).

Let $\pi_{i}^{*}-$ extreme of $\varphi_{i}$, than $\varphi_{i}^{*}=\varphi_{i}\left(\pi_{i}^{*}\right)-$ extreme solution. If it is exist such $\pi_{i}^{*}$, thatis $\forall i \in J_{n}$ : $\varphi_{i}^{*}=\varphi_{i}\left(\pi_{i}^{*}\right)$, and $\exists \Phi^{*}\left(\pi^{*}\right)=\left(\varphi_{1}^{*}, \varphi_{2}^{*}, \ldots, \varphi_{n}^{*}\right)$, so $\pi^{*}$ is an ideal solution of MCOP.

The set of all such elements is the set of ideal solutions of MCOP:

$$
\mathrm{I}(\Phi, \Pi)=\left\{\pi^{*} \in \Pi: \Phi\left(\pi^{*}\right)=\Phi^{*} .\right.
$$

However, the existence of an ideal element is unlikely, but it is possible to find an effective solution or effective solutions set.

Let $\pi^{\prime}, \pi^{\prime \prime} \in \Pi$, if for all $\varphi_{i}, i \in J_{n}$ inequalities hold $\varphi_{i}\left(\pi^{\prime}\right) \geq \varphi\left(\pi^{\prime \prime}\right)$ providing that extr $=\max$ and $\exists j \in J_{n} \varphi_{i}\left(\pi^{\prime}\right) \geq \varphi\left(\pi^{\prime \prime}\right)$, that said $\pi^{\prime}$ exceed $\pi^{\prime \prime}$ on $\Pi$, so $\pi^{\prime} \succ \pi^{\prime \prime}$. Accordingly, $\Phi\left(\pi^{\prime}\right)$ is better than $\Phi\left(\pi^{\prime \prime}\right)$, than is $\Phi\left(\pi^{\prime}\right) \succ \Phi\left(\pi^{\prime \prime}\right)$. Note that

$$
\left(\Phi\left(\pi^{\prime}\right)\right)=\Phi\left(\pi^{\prime \prime}\right) \Leftrightarrow\left(\forall i \in J_{n} \varphi_{i}\left(\pi^{\prime}\right)=\varphi\left(\pi^{\prime \prime}\right)\right) .
$$

For multiobjective problems it is used the effective solution concept. Effective solutions satisfy certain requirements. There are different types of effective solutions, the most common of which are Pareto-optimal solutions. Pareto optimal solutions are those that cannot be improved by any other solution [3], that is

$$
\begin{gathered}
P(\Phi, \Pi)=\{\pi \in \Pi\}: \nexists \pi^{\prime} \in \Pi: \Phi\left(\pi^{\prime}\right) \geq \Phi(\pi), \\
\Phi\left(\pi^{\prime}\right) \neq \Phi(\pi) .
\end{gathered}
$$

\section{Euclidean combinatorial multiobjective problem}

If the set $\Pi$ is a set of combinatorial configurations, then it can be possible to solve the multi-criteria combinatorial problem, to solve the problem in Euclidean space, on Euclidean combinatorial configurations $\mathrm{E}$ : find $P(F, X)$ for

$$
\begin{gathered}
F(x)=\left(f_{1}(x), f_{2}(x), \ldots, f_{n}(x)\right) \rightarrow \text { extr }, \\
x \in X \subseteq E,
\end{gathered}
$$

where $X \subseteq E-$ the set of feasible solutions, which is formed from the set of Euclidean combinatorial configurations with the help of additional restrictions; $f_{i}: X \rightarrow R^{1}, i \in J_{n}-$ partial optimality criteria; $n$ - number of functions.

Problem (1)-(2) is Euclidean multiobjective combinatorial optimization problem (EMCOP). The MCOP and EMCOP are equivalent, provided that there is bijective correspondence between their solutions.

Optimization on combinatorial configurations is closely related to the theory of combinatorial polyhedral and graph theory. This connection lies in the fact that combinatorial configurations match to polyhedrons, which are the convex hull of a configurations sets whose elements coincide with the vertices of a polyhedron [6-14].

Particular attention should be paid to the relationship between combinatorial configurations and graph theory. Since for a combinatorial permutation configuration it is possible to construct a configuration graph whose vertices coincide with the elements of the set [15-21].

Partitioning the graph into sub graphs according to a certain characteristic allows us to determine the subsets that can be analyzed in order to optimize the process of solving the problem. 


\section{The solving method for EMCOP}

To solve the above formulated problem, it can be used the method proposed earlier in [5], however, it should be noted that it is possible to improve and rationalize it by introducing an additional step of constraint analysis. As a result of the computational experiments, the authors noticed the fact that the closer the specified value of the constraint $b_{i}$ to the corresponding value of the function on the graph (the maximum for inequality of the form $g_{i}(x) \geq b_{i}$, or the minimum for $\left.g_{i}(x) \geq b_{i}\right)$, the fewer vertices of the graph are considered and the more points are cut off. The closer the value $b_{i}$ to an average of maximum and minimum of the restriction function on the graphmeansthe more points will be considered.

These results became the basis for the rationalization of the method, since in a situation when, after the formation of a set of configurations that satisfy the constraint, their number is much smaller than the initial one, then checking the resulting set to satisfy all remaining constraints may be less time-consuming than the complete execution of the coordinate method procedure with subsequent intersection of sets.

Thus, it is necessary to determine the constraints for which the differences $b_{i}-\min g_{i}$ and $\max g_{i}-b_{i}$ will be minimal. It is likely that in such cases, or most of the points will not be included in the desired set, i.e. or the power of the set will be much less than the initial one $\left|D_{i}\right|<|X|$. The larger the problem's dimension, the more relevant the preliminary analysis stage, since the method involves breaking the combinatorial configuration graph into grid graphs, and the larger the dimension, the more grid graphs need to be investigated. In addition, there is a problem with variable substitutions, since at the beginning of the procedure for each constraint function, its coefficients are sorted in ascending order, which entails the need to substitute the elements and then return to the original order. Given these features, the option not to consider all the many configurations, but only part of it, makes it possible to use computing resources more economically.

\section{Mathematical model of determining the effectiveness of real estate deposits taking into account losses}

Currently, models of such tasks are quite relevant. Given the current situation in the world, it should be noted that every factory, organization, business needs careful analysis and possible forecast. Obviously, all areas of the economy are suffering losses, so it is important to consider models of such problems.

Economics and planning are one of the important areas of multiobjective combinatorial optimization. If an enterprise plans to invest in real estate, it is advisable to calculate their effectiveness in order to determine the most profitable plan that will maximize profits and also be the least risky.

Let the company have $k$ assets to invest in $k$ real estate $-A=\left(a_{1}, \ldots, a_{k}\right)$. Suppose $x^{*}=\left(x_{1}, \ldots, x_{k}\right)$ that the required real estate deposit plan is to be found, where $x_{i}$ is the amount of the contribution to the $i$ real estate type.

The company has information about the risks of investing in real estate of $i$-th type $-c_{i}^{1}, i \in J_{k}$, projected rental income of $i$-th type $-c_{i}^{2}, i \in J_{k}$, maintenance costs of the $i$-thtype of real estate type $-c_{i}^{3}, i \in J_{k}$, the estimated magnitude of losses in emergencies $i$-th type of real estate $-c_{i}^{4}, i \in J_{k}$.

Thus, in order to obtain an optimal real estate investment plan, the following criteria should be optimized:

- amount of contribution risks:

$f_{1}(x)=\min \left\langle c_{i}^{1}, x\right\rangle, i \in J_{k}$;

- real estate rental income:

$f_{2}(x)=\min \left\langle c_{i}^{2}, x>, i \in J_{k}\right.$;

- maintenance costs of real estate:

$f_{3}=\min \left\langle c_{i}^{3}, x\right\rangle, i \in J_{k}$;

- estimated losses in emergency situations:

$f_{4}=\min \left\langle c_{i}^{4}, x\right\rangle, i \in J_{k}$.

Since the contribution to real estate is associated with the need for further maintenance costs, there are additional constraintsassociated with the resources of the enterprise $A_{i j} x_{j} \leq b_{j}$, where $i \in J_{m}$, $j \in J_{k}$ where $A_{i j}$ - the cost of resources of the 
$j$-th type of maintenance of the $i$-th type of real estate, $b_{j}-$ the availability of resources of the $j$-th type.

The mathematical model of the problem will look like: $x^{*}=\left(x_{1}, \ldots, x_{k}\right)-$ a plan for real estate investments that you need to find. The set $x^{*}=\left(x_{1}, \ldots, x_{k}\right)$ construct described above corresponds to the set of Euclidean combinatorial configurations $E$. Provided that all sums are different and can be used for the same period, then the set corresponds to the configurations of permutations $E_{n}(A)$. If the amounts are repeated, then we get a configuration of permutations with repetitions $E_{n}(A)$. Provided that the deposit options are less than the amounts available, then we will have combinatorial configurations of placements $E_{k}^{n}(A)$ or placements with repetitions accordingly $E_{q k}^{n}(A)$. Generalizing all the variants, we denote the combinatorial set by $X$. So we have the task: find the values that are optimal for the functions:

$$
\begin{aligned}
& f_{1}(x)=\min <c_{i}^{1}, x>, i \in J_{k}, \\
& f_{2}(x)=\min <c_{i}^{2}, x>, i \in J_{k},
\end{aligned}
$$

$$
\begin{aligned}
& f_{3}=\min \left\langle c_{i}^{3}, x>, i \in J_{k},\right. \\
& f_{4}=\min \left\langle c_{i}^{4}, x>, i \in J_{k},\right.
\end{aligned}
$$

and satisfies the constraints $A_{i j} x_{j} \leq b_{j}$.

This is an Euclidean multiobjective combinatorial optimization problem.

\section{Conclusion}

The article defines a multiobjective problem on Euclidean combinatorial configurations, gives an example of constructing a mathematical model for a practical problem. One of the possible approaches to solving the multiobjective problem on the permutation configurations set is described.

The properties of combinatorial configurations play an important role in the development of methods for solving combinatorial problems; therefore, further studies in this direction are aimed at studying such properties and their application to develop new and improve existing methods for solving the problems considered.

\section{REFERENCES}

1. Ehrgott, M., 2005. Multicriteria Optimization. Springer, Berlin : New York, 323 p.

2. Ehrgott, M., Gandibleux, X., 2003. "Multiobjective Combinatorial Optimization - Theory, Methodology, and Applications". In: Ehrgott, M. and Gandibleux, X. (eds.) Multiple Criteria Optimization: State of the Art Annotated Bibliographic Surveys, pp. 369-444. Springer US, https://doi.org/10.1007/0-306-48107-3_8.

3. Tymofiyeva, N.K., Grytsenko, V.I., 2017. "Combinatory in the Artificial Intellect Problems". Upravlausie sistemi i masiny, 2, pp. 6-19, 37. [Тимофієва Н.К., Гриценко В.І. Комбінаторика в задачах штучного інтелекту. Управляющие системы и машины. 2017. № 2. С. 6-19, 37 (In Ukrainian)].

4. Koliechkina, L., Pichugina, O., 2018. "Multiobjective Optimization on Permutations with Applications". DEStech Transactions on Computer Science and Engineering, pp. 61-75, https://doi.org/10.12783/dtcse/optim2018/27922.

5. Koliechkina, L. N., Dvirna, O. A., Nagornaya, A.N., 2014. "Modified Coordinate Method to Solve Multicriteria Optimization Problems on Combinatorial Configurations”. Cybernetics and Systems Analysis, 59 (4), pp. 620-626.

6. Korte, B., Vygen, J., 2018. Combinatorial Optimization: theory and algorithms. Heidelberg; New York:Springer, $698 \mathrm{p}$.

7. Pardalos, P.M., Du, D-Z., Graham, R.L., 2013. Handbook of combinatorial optimization. New York : Springer, 3409 p.

8. Papadimitriou, C.H., Steiglitz, K., 2013. Combinatorial optimization: algorithms and complexity. Mineola : Dover Publications, $528 \mathrm{p}$. 
9. Sergienko, I.V., Shilo, V.P., 2016. "Modern approaches to solving complex discrete optimization problems". Journal of Automation and Information Sciences, 48(1), pp.15-24.

10. Hulianytskyi, L., Riasna, I., 2017. "Formalization and classification of combinatorial optimization problems". Optimization Methods and Applications, S. Butenko et al.(eds.). Springer, New York, pp. 239-250.

11. Farzad, B., Pichugina, O., Koliechkina, L., 2018. "Multi-Layer Community Detection". In: 2018 International Conference on Control, Arti cial Intelligence, Robotics Optimization (ICCAIRO). Pp. 133-140.

12. Koliechkina, L., Pichugina, O., 2019. "A Horizontal Method of Localizing Values of a Linear Function in PermutationBased Optimization”. In: Le Thi, H.A., Le, H.M., and Pham Dinh, T. (eds.) Optimization of Complex Systems: Theory, Models, Algorithms and Applications, Springer, Cham, pp. 355-364. https://doi.org/https://doi.org/10.1007/978-3030-21803-4_36.

13. Koliechkina, L., Pichugina, O., Yakovlev, S., 2020. "A Graph-Theoretic Approach to Multiobjective Permutation-Based Optimization”. In: Jacimovic, M., Khachay, M., Malkova, V., and Posypkin, M. (eds.) Optimization and Applications, Springer International Publishing, Cham, pp. 383-400.

14. Koliechkina, L., Nahirna, A., Dvirna, O., 2019. "Quadratic Optimization Problemon Permutation Setwith Simulationof Applied Tasks" [Electronic optimiza]. Proceedings of the Second International Workshop on Computer Modeling and Intelligent Systems (CMIS-2019), Zaporizhzhia, Ukraine, April 15-19, 2019, pp. 651-663. (CEUR Workshop Proceedings, Vol. 2353). Access mode: http://ceur-ws.org/Vol-2353/paper52.pdf

15. Kozin, I.V., Kryvtsun, O.V., Pinchuk, V.P., 2015. "Evolutionary-Fragmentary Model of the Routing Problem”. Cybern. Syst. Anal., 51, pp. 432-437.

16. Kozin, I.V., Maksyshko, N.K., Perepelitsa, V.A.,2017. "Fragmentary Structures in Discrete Optimization Problems". Cybern. Syst. Anal., 53, pp. 931-936.

17. Yakovlev, S., Pichugina, O., 2019. "On Constrained Optimization of Polynomials on Permutation Set". In: Proceedings of the Second International Workshop on Computer Modeling and Intelligent Systems (CMIS2019). Pp. 570-580. CEUR Vol-2353 urn:nbn:de:00742353-0, Zaporizhzhia, Ukraine. http://ceur-ws.org/Vol2353/paper45.pdf

18. Yakovlev, S., Pichugina, O., Yarovaya, O., 2019. "Polyhedral-spherical con gurations in discrete optimization problems". Journal of Automation and Information Sciences, 51, pp. 26-40. https://doi.org/DOI: 10.1615/JautomatInfScien. v51.i1.30.

19. Emets, O.A., Nedobachii, S.I., Kolechkina, L.N., 2009. "An irreducible set of combinatorial polyhedron constraints in the linear-fractional optimization problem on permutations". Discrete Mathematics and Applications. 11, pp. 95103. https://doi.org/10.1515/dma.2001.11.1.95.

20. Chase, P., 1973. "Transposition Graphs”. SIAM J. Comput. 2, pp. 128-133.

21. Donets, G., Koliechkina, L., Nahirna, A., 2020. "A Method to Solve Conditional Optimization Problems with Quadratic Objective Functions on the Set of Permutations”. Cybernetics and Systems Analysis, 56 (2), pp. $278-288$.

Received 14.04.2020 
Колєчкіна Л.М., док. фіз.-мат. наук, професор, Лодзький університет, вул. Банаха 22, Лодзь 90-238, Польща, lkoliechkina@gmail.com,

Двірна О.А., канд. фіз.-мат. наук, асистент, Полтавський університет економіки і торгівлі, вул. Коваля, 3, 36000, Україна, lenadvirna@gmail.com

Нагірна А.М., канд. фіз.-мат. наук, доцент, Національний університет «Києво-Могилянська академія», вул. Г. Сковороди, 2, м. Київ, 04070, Україна, naghirnaalla@ukr.net

\section{ПОБУДОВА МАТЕМАТИЧНОЇ МОДЕЛІ БАГАТОКРИТЕРІАЛЬНОЇ ОПТИМІЗАЦЇ̈ НА ПЕРЕСТАНОВКАХ}

Вступ. Задача оптимізації декількох функцій виникає при дослідженні багатьох теоретичних та прикладних проблем. Практично будь-яка задача оптимального проектування складних економічних і технічних систем, схем, технологічних пристроїв, конструкцій, планування і управління виробничою й комерційною діяльністю, ідентифікації параметрів моделі за експериментальними даними вимагає, щоб шуканий розв'язок знаходився 3 урахуванням багатьох критеріїв. Оскільки неможливо адекватно виразити одним комплексним критерієм умови задачі, то для обліку всіх вимог прикладної задачі доцільніше використовувати апарат багатокритеріальної оптимізації. Це означає, що апарат класичної однокритеріальної оптимізації є недостатнім для пошуку і прийняття ефективних розв'язків прикладних задач.

Мета. Стаття присвячена побудові багатокритеріальних математичних моделей прикладних задач на комбінаторних конфігураціях та їх розв'язанню. Це питання $є$ актуальним, тому що будь-яка задача оптимального проектування складних економічних і технічних систем, технологічних пристроїв, планування і управління вимагає, щоб було знайдено бажаний розв'язок з урахуванням багатьох критеріїв.

Методи. В статті здійснюється перехід до евклідових комбінаторних конфігурацій, використовуються методи дискретної та багатокритеріальної оптимізації.

Результати. Побудовано модель для визначення планів вкладу в нерухомість і виробничого планування, яка представлена як багатокритеріальна дискретна задача. Представлено метод розв'язання такої задачі, що включає аналіз структурного графа множин евклидових комбінаторних конфігурацій. Даний метод може бути змінений шляхом сполучення з іншими багатокритеріальними методами оптимізації в залежності від початкових умов задачі.

Висновки. Запропоновану багатокритеріальну модель можна доповнювати по мірі необхідності певними функціями, і в залежності від початкових умов, представляти у вигляді задач на різних множинах комбінаторних конфігурацій. Розглянутий метод можна використовувати для розв’язування даного класу задач.

Ключові слова: задача оптимізації, комбінаторні конфігурації, Евклідовий комбінаторний простір, модель задач оптимізації, множина оптимальних розв'язків. 
Колечкина Л.Н., док. физ.-мат. наук, профессор, Лодзинский университет, ул. Банаха 22,

Лодзь 90-238, Польша,

lkoliechkina@gmail.com,

Дверная Е.А., канд. физ.-мат. наук, ассистент,

Полтавський университет экономики и торговли,

ул. Коваля, 3, 36000, Украина,

lenadvirna@gmail.com

Нагорная А.Н., канд. физ.-мат. наук, доцент,

Национальный университет «Киево-Могилянская академия», ул. Г. Сковороды, 2, м. Киев, 04070, Украина, naghirnaalla@ukr.net

\section{ПОСТРОЕНИЕ МАТЕМАТИЧЕСКОЙ МОДЕЛИ \\ МНОГОКРИТЕРИАЛЬНОЙ ОПТИМИЗАЦИИ НА ПЕРЕСТАНОВКАХ}

Введение. Задача оптимизации нескольких функций возникает при исследовании многих теоретических и прикладных проблем. Практически любая задача оптимального проектирования сложных экономических и технических систем, схем, технологических устройств, конструкций, планирования и управления производственной и коммерческой деятельностью, идентификации параметров модели по экспериментальным данным требует, чтобы искомое решение находилось с учетом многих критериев. Соответственно, поскольку невозможно адекватно выразить одним комплексным критерием условия задачи, для учета всех требований прикладной задачи целесообразнее использовать аппарат многокритериальной оптимизации. Это означает, что аппарата классической однокритериальной оптимизации недостаточно для поиска и принятия эффективных решений прикладных задач.

Цель. Статья посвящена проблеме построения многокритериальных математических моделей прикладных задач на комбинаторных конфигурациях и их решению. Этот вопрос является актуальным, потому что любая задача оптимального проектирования сложных экономических и технических систем, технологических устройств, планирования и управления требует, чтобы было найдено желаемое решение с учетом многих критериев.

Методы. В статье используется переход к евклидовым комбинаторным конфигурациям, а также методы дискретной и многокритериальной оптимизации.

Результаты. Построена модель для определения планов вклада в недвижимость и производственного планирования как многокритериальная дискретная задача. Представлен метод решения такой задачи, включающий анализ структурного графа множеств евклидовых комбинаторных конфигураций. Этот метод может быть изменен путем сочетания с другими многокритериальными методами оптимизации в зависимости от начальных условий задачи.

Выводы. Предложенную многокритериальную модель можно дополнять по мере необходимости требуемыми функциями и, в зависимости от начальных условий, представлять в виде задач на различных множествах комбинаторных конфигураций. Рассмотренный метод можно использовать для решения данного класса задач.

Ключевые слова: задача оптимизации, комбинаторные конфигурации, Евклидово комбинаторное множество, модель оптимизационных задач, множество оптимальных решений. 